\title{
ANALISIS DETERMINAN YANG MEMPENGARUHI KEJADIAN EKLAMPSIA PADA IBU HAMIL PREEKLAMPSIA DI RSI SULTAN AGUNG SEMARANG
}

\author{
Desi Sariyani \\ STIKes Bakti Utama Pati, Jl. Ki Ageng Selo No. 15 Pati, 081225534700 \\ Email:desisariyanii@gmail.com
}

\begin{abstract}
ABSTRAK
Eklampsia di Indonesia adalah penyakit dengan prevalensi tertinggi di Indonesia. Penyebab pasti terjadinya eklampsia belum diketahui, namun terdapat factor resiko yang mempengaruhi kejadian eklampsia. Tujuan dari penelitian ini adalah untuk mengetahui hubungan usia, status gravida, dan usia kehamilan dengan kejadian eklampsia di RSI Sultan Agung Semarang Tahun 2015.Metode. Desain penelitian dalam penelitian ini adalah survey analitik dengan menggunakan pendekatan cross sectional, data diambil dari data rekam medis RSI Sultan Agung kota Semarang. Populasi dalam penelitian ini adalah ibu hamil dengan preeklampsia sebanyak 103 yang diperoleh dengan teknik total sampling. Analisis data dengan menggunakan uji Chi Square. Hasil. Penelitian menunjukkan ada hubungan yang signifikan antara usia dengan eklampsia pada ibu hamil preeklampsia dengan p-value 0,001<a 0,05, ada hubungan antara status gravida dengan kejadian eklampsia pada ibu hamil preeklampsia dengan p-value 0,001< $\alpha 0,05$, dan ada hubungan antara usia kehamilan dengan kejadian eklampsia pada ibu hamil preeklampsia dengan $p$-value 0,001 < a 0,05. Kesimpulan. Berdasarkan hasil penelitian diharapkan ibu dengan usia <20 tahun menunda kehamilannya dan pada ibu hamil dengan usia >35 tahun diharapkan memiliki kesadaran yang tinggi untuk melakukan ANC (antenatal care) secara teratur kepada petugas kesehatan.
\end{abstract}

Kata Kunci: usia, status gravida, usia kehamilan, preeklampsia, eklampsia.

\begin{abstract}
Eclampsia in Indonesia is the disease with the highest prevalence in Indonesia. The exact cause of eclampsia is not yet known, but there are risk factors that affect the incidence of eclampsia. The purpose of this study was to determine the relationship of age, status gravida, and gestational age with the incidence of eclampsia in RSI Sultan Agung Semarang 2015. Design of this research was analytic survey with cross sectional approach; data is extracted from the medical records RSI Sultan Agung Semarang. The population in this study were pregnant women with preeclampsia as many as 103 . The sample in this study was 103, obtained by total sampling technique. Data analysis used Chi Square test. The results showed no significant correlation between the age of eclampsia in pregnant women with preeklampsia with a p-value $0.001<\alpha 0.05$, there is a relationship between status gravida with the incidence of eclampsia in pregnant women with preeklampsia $p$-value $0.001<\alpha 0,05$, and there is a relationship between the incidence of pregnancy with preeclampsia-eclampsia in pregnant women with a p-value $0.001<\alpha 0.05$. Based on the results of the study are expected maternal age $<20$ years of delaying pregnancy and maternal age $>35$ years is expected to have a high awareness to ANC (antenatal care) regularly to health workers.
\end{abstract}

Keywords: age; gestation; gravida; preeklampsia; eclampsia 


\section{LATAR BELAKANG}

Eklampsia merupakan keadaan dimana ditemukan serangan kejang tiba-tiba yang dapat disusul dengan koma pada wanita hamil, persalinan, dan masa nifas yang menunjukkan gejala preeklampsia sebelumnya. Kejang disini bersifat grand mal dan bukan diakibatkan oleh kelainan neurologis (Ahmed et al, 2014).

Ada banyak factor resioko yang mempengaruhi terjadinya preeklampsia/ eklampsia, seperti primigravida, hiperplasentosis, usia ibu yang ekstrim $(<20$ tahun dan $>35$ tahun), riwayat keluarga pernah preeklampsia/ eklampsia, penyakit ginjal, diabetes mellitus, hipertensi kronik yang sudah diderita sebelum hamil, dan obesitas (Elizabeth, 2011).

Preeklampsia/eklampsia lebih sering terjadi pada primigravida dibandingkan dengan multigravida. Dari seluruh primigravida 7,6\% didiagnosis menderita preeklampsia. Primigravida mempunyai risiko yang lebih besar untuk mengalami preeklampsia/ eklampsia karena pada primigravida mekanisme imunologik dalam pembentukan blocking antibody terhadap antigen plasenta oleh HLA-G (human leukocyte antigen G) belum sempurna dibandingkan dengan multi (Dollar, 2008).

Faktor lain yang mempengaruhi ialah pada usia kehamilan. Berdasarkan teori adaptasi kardiovaskuler bahwa pada hipertensi dalam kehamilan kehilangan daya refakter terhadap bahan vasokonstriktor dan ternyata terjadi peningkatan kepekaan terhadap bahan-bahan vasopressor. Artinya, daya refrakter pembuluh darah terhadap bahan vasopressor hilang sehingga pembuluh darah menjadi sangat peka terhadap bahan vasopressor. Peningkatan kepekaan terhadap bahan vasopressor pada hipertensi dalam kehamilan sudah terjadi pada trimester I (pertama). Peningkatan kepekaan pada kehamilan yang akan menjadi hipertensi dalam kehamilan dua puluh minggu (Judy dan Maureen, 2013).

Faktor lain yang dapat meningkatkan kejadian preeklampsia dan eklampsia ialah riwayat preeklampsia sebelumnya, riwayat keluarga dengan preeklampsia, kehamilan kembar, kondisi medis tertentu, adanya proteinuria, obesitas, dan fertilitas in vivo (Judy dan Maureen, 2013). Perempuan yang memiliki banyak faktor resiko dengan riwayat penyakit yang buruk dan sebelumnya mengalami awitan resiko preeklampsia sejak dini meningkatkan resiko 20\% Ahmed et al, (2014). Ibu yang mengalami preeklampsia, $26 \%$ anak perempuannya akan mengalami preeklampsia pula, sedangkan hanya $8 \%$ anak menantu mengalami preeklampsia (Manuaba, 2010).

Dampak atau komplikasi terberat ialah kematian ibu dan janin. Usaha utama ialah melahirkan bayi hidup dari ibu yang menderita preeklampsia dan ekalmpsia. Komplikasi lain yang dapat muncul antara lain ialah: solusio plasenta, hemolisis, perdarahan otak,edema paru, nekrosis hati, kelainan ginjal, dan komplikasi lain seperti lidah tergigit dan prematuritas (Manuaba, 2010).

Sebagai upaya untuk menurunkan Angka Kematian Ibu (AKI), telah dilaksanakan berbagai pelatihan peningkatan kualitas pelayanan kesehatan ibu dan anak diantaranya Pelatihan Asuhan Persalihan Normal (APN) yang merupakan standar pertolongan persalinan dan pendampingan persalinan dukun bayi oleh tenaga kesehatan, Pelayanan Obstetri dan Neonatal Emergensi Dasar (PONED) dan Pelayanan Obstetri dan Neonatal Emergensi Komprehensif (PONEK) serta yang lainnya (Dinkes Semarang, 2014).

Berdasarkan survey pendahuluan dengan melihat 14 rekam medis pasien preeklampsia di RSI Sultan Agung Semarang, didapatkan bahwa $53,3 \%$ pasien yang berusia $20-35$ tahun, $60 \%$ pasien merupakan primipara, $26,7 \%$ pasien dengan jarak persalinan $<2$ tahun, $66,7 \%$ pasien dengan pekerjaan sebagai buruh di pabrik, 46,7\% pasien dengan riwayat hipertensi, $60 \%$ pasien dengan diagnose utama preeklampsia menjadi eklampsia. Selain itu, pada tahun 2013 terdapat kasus preeklampsia sebanyak 43 dan meningkat menjadi 87 kasus pada tahun 2014. Berdasarkan hasil survey awal dan meningkatnya angka kejadian preeklampsia tersebut sehingga membuat peneliti tertarik untuk melakukan penelitian yang bertujuan untuk mengetahui beberapa factor yang berhubungan dengan kejadian eklampsia pada 
ibu hamil dengan preeklampsia di RSI Sultan Agung Semarang Tahun 2015.

\section{METODE}

Metode penelitian yang digunakan oleh peneliti adalah penelitian survei analitik dengan menggunakan desain cross-sectional. Penelitian ini dilaksanakan di RSI Sultan Agung Semarang karena 60\% pasien dengan diagnose utama preeklampsia menjadi eklampsia. Populasi dalam penelitian ini adalah keseluruhan ibu hamil dengan preeklampsia yang rawat inap di RSI Sultan Agung Semarang pada Bulan Januari-Desember 2015 sejumlah 103 orang. Sampel yang digunakan pada penelitian ini adalah seluruh populasi ibu hamil dengan preeklampsia yang berjumlah 103 orang. Teknik sampling yang digunakan dalam penelitian ini adalah total sampling dengan mengambil semua anggota populasi untuk dijadikan sampel.

Sumber data yang diambil dalam penelitian ini adalah data sekunder yaitu dari rekam medis di RSI Sultan Agung Semarang Bulan Januari- Desember 2015. Pengumpulan data dilakukan dengan cara mempelajari catatan rekam medis.

Instrumen penelitian yang digunakan dalam penelitian ini menggunakan lembar observasii yang digunakan untuk memperoleh data tentang karakteristik penyebab kejadian eklampsia di RSI Sultan Agung Semarang.Uji statistik yang digunakan adalah uji chi square.

\section{HASIL}

Tabel 1 Hubungan Usia dengan Kejadian Eklampsia pada Ibu Hamil Preeklampsia yang Rawat Inap di RSI Sultan Agung Semarang

\begin{tabular}{|c|c|c|c|c|c|c|c|}
\hline \multirow{3}{*}{ Usia } & \multicolumn{4}{|c|}{$\begin{array}{l}\text { Kejadian } \\
\text { Eklampsia }\end{array}$} & \multirow{2}{*}{\multicolumn{2}{|c|}{ Total }} & \multirow{3}{*}{$\begin{array}{c}\text { p- } \\
\text { value }\end{array}$} \\
\hline & \multicolumn{2}{|c|}{ Ya } & \multicolumn{2}{|c|}{ Tidak } & & & \\
\hline & $f$ & $\%$ & $f$ & $\%$ & $f$ & $\%$ & \\
\hline$<20$ tahun & 21 & $\begin{array}{c}100 \\
0\end{array}$ & 0 & 0 & 21 & 100,0 & 0,001 \\
\hline 20- 35 tahun & 15 & 30,0 & 35 & 70,0 & 50 & 100,0 & \\
\hline$>35$ tahun & 17 & 53,1 & 15 & 46,9 & 32 & 100,0 & \\
\hline Jumlah & 53 & 51,5 & 50 & 48,5 & 103 & & \\
\hline
\end{tabular}

Berdasarkan tabel 1, menunjukkan bahwa sebagian besar ibu hamil preeklampsia yang mengalami eklampsia berusia $<20$ tahun sebanyak $21(100,0 \%)$ dan yang berusia $>35$ tahun sebanyak $17(53,1 \%)$ dibandingkan ibu hamil berusia reproduktif (20-35 tahun) sebanyak 15 (30,0\%). Dari hasil uji statistic untuk menganalisa hubungan antara usia dengan kejadian eklampsia menggunakan uji Chi Square diperoleh nilai $p$-value 0,001 ( $p<$ 0,05 ), disimpulkan bahwa ada hubungan yang signifikan antara usia dengan kejadian eklampsia pada ibu hamil preeklampsia yang rawat inap di RSI Sultan Agung Semarang.

Tabel 2 Hubungan Status Gravida dengan Kejadian Eklampsia pada Ibu Hamil dengan Preeklampsia yang Rawat Inap di RSI Sultan Agung Semarang

\begin{tabular}{|c|c|c|c|c|c|c|c|}
\hline \multirow{3}{*}{$\begin{array}{l}\text { Status } \\
\text { Gravida }\end{array}$} & \multicolumn{4}{|c|}{$\begin{array}{l}\text { Kejadian } \\
\text { Eklampsia }\end{array}$} & \multirow{2}{*}{\multicolumn{2}{|c|}{ Total }} & \multirow{3}{*}{$\begin{array}{c}\text { p- } \\
\text { value }\end{array}$} \\
\hline & \multicolumn{2}{|c|}{ Ya } & \multicolumn{2}{|c|}{ Tidak } & & & \\
\hline & $\mathbf{F}$ & $\%$ & $\mathbf{F}$ & $\%$ & $\mathbf{F}$ & $\%$ & \\
\hline Primipara & 31 & 67,4 & 15 & 32,6 & 46 & 100,0 & 0,001 \\
\hline Multipara & 10 & 26,3 & 28 & 73,7 & 38 & 100,0 & \\
\hline $\begin{array}{l}\text { Grandemul } \\
\text { tipara }\end{array}$ & 12 & 63,2 & 7 & 36,8 & 19 & 100,0 & \\
\hline Jumlah & 53 & 51,5 & 50 & 48,5 & 103 & & \\
\hline
\end{tabular}

Berdasarkan tabel 2, dapat dijelaskan hubungan antara status gravida dengan kejadian eklampsia. Dari tabel diatas menunjukkan bahwa 46 responden mayoritas ibu hamil preeklampsia dengan primipara dan yang mengalami ekampsia dengan prosentase 67,4\% dibandingkan pada grandemultipara dari 19 responden yang mengalami eklampsia dengan prosentase $63,2 \%$. Proporsi ibu hamil preeklampsia yang tidak mengalami eklampsia lebih banyak pada multipara dengan prosentase $73,7 \%$ dibandingkan dengan primipara $32,6 \%$ dan grandemultipara $36,8 \%$. Hasil uji statistic dengan Chi square didapatkan nilai $p=0,001(p<0,05)$, maka Ho ditolak dan Ha diterima. Secara statistic dapat disimpulkan bahwa terdapat hubungan signifikan antara status gravida dengan kejadian eklampsia. 
Tabel 3 Hubungan Usia Kehamilan dengan Kejadian Eklampsia pada Ibu Hamil dengan Preeklampsia yang Rawat Inap di RSI Sultan Agung Semarang

\begin{tabular}{|c|c|c|c|c|c|c|c|}
\hline \multirow{3}{*}{$\begin{array}{c}\text { Usia } \\
\text { Kehamilan }\end{array}$} & \multicolumn{4}{|c|}{$\begin{array}{c}\text { Kejadian } \\
\text { Eklampsia }\end{array}$} & \multirow{2}{*}{\multicolumn{2}{|c|}{ Total }} & \multirow{3}{*}{$\underset{\text { value }}{p-}$} \\
\hline & \multicolumn{2}{|c|}{$\mathrm{Ya}$} & \multicolumn{2}{|c|}{ Tidak } & & & \\
\hline & $F$ & $\%$ & $f$ & $\%$ & $f$ & $\%$ & \\
\hline 20-37 minggu & 4 & 14,3 & 24 & 85,7 & 28 & 100,0 & 0,001 \\
\hline >37 minggu & 49 & 65,3 & 26 & 34,7 & 75 & 100,0 & \\
\hline Jumlah & 53 & 51,5 & 50 & 48,5 & 103 & & \\
\hline
\end{tabular}

Berdasarkan tabel 3, menunjukkan bahwa mayoritas ibu hamil preeklampsia memiliki usia kehamilan >37 minggu dan sebagian besar ibu hamil yang mengalami eklampsia dengan prosentase $65,3 \%$ dibandingkan yang tidak mengalami eklampsia dengan prosentase $34,7 \%$. Hasil uji statistic dengan Chi square didapatkan nilai $p=0,001(p<0,05)$, maka Ho ditolak dan Ha diterima. Secara statistic dapat disimpulkan bahwa terdapat hubungan signifikan antara usia kehamilan dengan kejadian eklampsia.

\section{PEMBAHASAN}

Preeklampsia adalah peningkatan tekanan darah yang baru timbul setelah kehamilan mencapai 20 minggu, disertai dengan penambahan berat badan ibu yang cepat akibat odema dan pada pemeriksaan laboratorium dijumpai protein dalam (Fadlun,2012).

Berdasarkan hasil uji statistic untuk menganalisa hubungan antara usia dengan kejadian eklampsia menggunakan uji Chi Square diperoleh nilai $p$-value $0,001(p<0,05)$, disimpulkan bahwa ada hubungan yang signifikan antara usia dengan kejadian eklampsia pada ibu hamil preeklampsia yang rawat inap di RSI Sultan Agung Semarang. Hasil penelitian ini sesuai dengan penelitian Abdul Gafur (2012) dengan hasil p-value 0.000 dan nilai OR 5.089 yang artinya usia $<20$ atau >35 tahun memiliki resiko sebesar 5.089 kali dibandingkan ibu yang memiliki usia 20-35 tahun terhadap kejadian eklampsia. Menurut Chunningham et al (2010) Pada usia < 20 tahun rentang mengalami gangguan sel endotel. Sel endotel merupakan lapisan bagian dalam lumen pembuluh darah yang berperan sebagai penghubung antara sirkulasi darah dan sel-sel otot polos. Jika sel endotel mengalami gangguan seperti stress maka fungsi pengaturan abnormal atau yang disebut dengan disfungsi endotel. Disfungsi endotel dapat menyebabkan ketidakseimbangan substansi vasoaktif yang dapat meningkatkan tekanan darah, disfungsi endotel juga menyebabkan permeabilitas vascular meningkat sehingga menyebabkan odema dan peningkatan proteinuria.Pada usia $>35$ tahun ini terjadi penurunan curah jantung yang disebabkan kontraksi miokardium, ditambah lagi dengan tekanan darah dan penyakit lain yang melemahkan kondisi ibu, sehingga dapat mengganggu sirkulasi darah kejanin yang beresiko meningkatkan komplikasi medis pada kehamilan antara lain keguguran, eklampsia, dan perdarahan. Tinggi rendahnya usia seseorang memengaruhi terjadinya preeklampsia dan eklampsia (Sarwono, 2012).

Pada primigravida sering mengalami stress dalam menghadapi persalinan. Stress emosi yang terjadi pada primigravida menyebabkan peningkatan pelepasan corticotropic releasing hormone $(\mathrm{CRH})$ oleh hipotalamus, yang kemudian menyebabkan peningkatan kortisol. Efek kortisol adalah mempersiapkan tubuh untuk berespon terhadap semua stressor dengan meningkatkan respon simpatis, termasuk respon yang ditujukan untuk meningkatkan curah jantung dan mempertahankan tekanan darah (Corwin, 2009).

Hipertensi dalam kehamilan terjadi akibat kombinasi peningkatan curah jantung dan resistensi perifer total. Selama kehamilan normal, volume darah meningkat secara drastic. Pada wanita sehat, peningkatan volume darah diakomodasikan oleh penurunan responsivitas vascular terhadap hormonehormone vasoaktif. Hal ini menyebabkan resistensi perifer total berkurang pada kehamilan normal dan tekanan darah rendah. Pada wanita dengan preeklampsia dan eklampsia, tidak terjadi penurunan sensitivitas terhadap vasopeptida-vasopeptida tersebut, sehingga peningkatan besar volume darah 
langsung meningkatkan curah jantung dan tekanan darah (Corwni, 2009).

Pada kehamilan normal, arteri spiralis yang terdapat pada desidua mengalami pergantian sel dengan trofoblas endovaskuler yang akan menjamin lumennya tetap terbuka untuk memberikan aliran darah tetap terbuka untuk memberikan aliran darah tetap, nutrisi cukup dan $\mathrm{O}_{2}$ seimbang. Hal tersebut dibutuhkan janin dalam rahim. Invasi trimester kedua pada preeklampsia dan eklampsia tidak terjadi sehingga terjadi hambatan pada saat memerlukan tambahan aliran darah untuk memberikan nutrisi dan $\mathrm{O}_{2}$. Keadaan ini dapat menerangkan bahwa preeklampsia akan meningkat pada usia kehamilan $>37$ minggu (Powe et al, 2011).

Hal ini sesuai dengan penelitian Harefa dan Sudarta (2013) dengan judul hubungan karakteristik ibu hamil dengan kejadian preeklampsia/ eklampsia di RS Santa Elizabeth Medan, berdasarkan hasil uji statistic dengan chi square didapatkan nilai $p=0,000(p<0,05)$ berarti bahwa terdapat hubungan signifikan antara usia kehamilan ibu dengan kejadian preeklampsia/ eklampsia dengan nilai $\mathrm{OR}=0,208$ artinya ibu dengan usia kehamilan >37 minggu mempunyai risiko 0,208 kali mengalami preeklampsia/ ekalampsia dibandingkan dengan usia kehamilan >37 minggu.

Preeklampsia/ eklampsia sering muncul setelah kehamilan >37 minggu, hal ini disebabkan kerja plasenta yang semakin aktif untuk pengembalian nutrisi bagi janin sehingga menyebabkan kenaikan tekanan darah sebagai tanda meningkatnya metabolisme organ tubuh ibu. Untuk itu, pemeriksaan kehamilan (antenatal care) yang teratur dan secara rutin tanda-tanda preeklampsia sangat penting dalam usaha pencegahan preeklampsia dan eklampsia, karena semakin tua umur kehamilan, resiko untuk mengalami preeklampsia/ ekalmpsia akan semakin tinggi

\section{KESIMPULAN DAN SARAN}

Ada hubungan antara usia, status gravida, dan usia kehamilan ibu hamil preeklampsia dengan kejadian eklampsia di RSI Sultan Agung Semarang.

Pencegahan resiko kejadian eklampsia dapat dilakukan ibu hamil dengan menunda kehamilan pada usia $<20$ tahun dan bila hamil pada usia $>35$ tahun maka perlu memeriksakan kehamilan (antenatal care) secara rutin untuk mencegah dan meminimalisir terjadinya preeklampsia

Diharapakan hasil penelitian ini dapat menambah wawasan bagi peneliti terutama yang berhubungan dengan kejadian eklampsia sehingga peneliti dapat mengemukakan factor lain yang menyebabkan kejadian eklampsia dan menganalisis kekurangan dari penelitian ini sehingga penelitian dapat memperoleh hasil yang lebih baik.

\section{REFERENSI}

Ahmed R, Dunford J, Mehran R, Robson S, Kunadian V. (2014). Pre-eclampsia and future cardiovascular risk among women: a review. J Am Coll Cardiol. 63(18):1815-1822.

Bothamley Judy dan Boyle Maureen. (2013). Patofisiologi dalam Kebidanan. Jakarta: EGC

Cunningham FG, Leveno KJ, Hauth JC, Bloom SL, Rouse DJ, Spong CY. (2010). Williams obstetric 23rd Edition. New York: McGraw-hill Companies.

Denantika, Oktaria. (2014). Hubungan Status Gravida dan Usia Ibu Terhadap Kejadian Preeklampsia di RSUD dr. M. Djamil Padang 2012-2013

Depkes RI. (2014). Profil Kesehatan Jawa Tengah 2014. Jateng

Dinas Kesehatan Kota Semarang. (2014). Profil Kesehatan Kota Semarang 2014. Semarang

Dollar. (2008). Hubungan Karakteristik Ibu Hamil Dengan Kejadian Preeklampsia/Eklampsia di RSUD dr. Pirngadi Medan Tahun 2006-2007. Skripsi FKM USU.

Elizabeth Robson, S. (2011). Patologi pada Kehamilan. Jakarta: EGC 
Fadlun. (2012). Asuhan Kebidanan Patologis. Jakarta: Salemba Medika

Gunawan. (2010). Bab 1-2.pdf (Secured). BabII Landasan Teori-upn Veteran Jakarta, http://www.library.upnvj.ac.id/pdf/4S1 kedokteran/207311168/Bab\%201. pdf. Diakses 16 Desember 2015.

Guyton, Arthur C., John E. Hall. (2012). Buku Ajar Fisiologi Kedokteran (Textbook of Medical Physiology, 11th edition). Jakarta: EGC Medical Publisher

Hidayat, Aziz Alimul. (2014). Metode Penelitian Kebidanan dan Teknik Analisis Data. Jakarta: Salemba Medika

Hanum, Huda dan Faridah BD. (2013). Faktor Risiko yang Berhubungan Dengan Kejadian Preeklamsia pada Ibu Bersalin di RSUP dr. M. Djamil Padang Tahun 2013. Disertasi Poltekkes Kemenkes Jurusan Kebidanan Padang.

Kemenkes RI. (2014). Profil Kesehatan Indonesia 2014. Jakarta.

Macdonald-Wallis C, Lawlor DA, Heron J, Fraser A, Nelson SM, Tilling K. (2011). Relationships of Risk Factors for PreEclampsia with Patterns of Occurrence of Isolated Gestational Proteinuria during Normal Term Pregnancy. PLOS ONE 6(7): e22115. retrieved from https://doi.org/10.1371/journal.pone.0022 115
Manuaba, IAC., I Bagus, dan IB Gde. (2010). IImu Kebidanan, Penyakit Kandungan dan KB untuk Pendidikan Bidan. Edisi kedua. Jakarta: EGC.

Osungbade, K, O, (2011). Publich Heaalth Perspektive of Preeklampsia in Developing Countries. Implication for Health System Strengthening. International Jurnal of Pregnancy

Prawirohardjo, Sarwono. (2012). IImu Kandungan. Jakarta: Yayasan Bina Pustaka.

Powe, C. E., Ecker, J., Rana, S., Wang, A., Ankers, E., Ye, J., Thadhani, R. (2011). Preeklampsia and the risk of large-forgestational-age infants. American journal of obstetrics and gynecology, 204(5), 425.e1-425.e4256. retrieved from doi:10.1016/j.ajog.2010.12.030

RSI Sultan Agung, (2015). Laporan Tahunan Rekam Medis. Jawa Tengah

Sari, Mayang. (2013). Faktor-Faktor Yang Berhubungan Dengan Kejadian Preeklampsia Pada Ibu Hamil Di Rumah Sakit Roemani Muhammadiyah. Jawa Tengah

Setiawan, Ari dan Saryono. (2011). Metode Penelitian Kebidanan. Yogyakarta: Muha Medika

Siswosudarmo, R., (2008). Obstetric Fisiologi. Yogyakarta: Pustaka Cendikia 